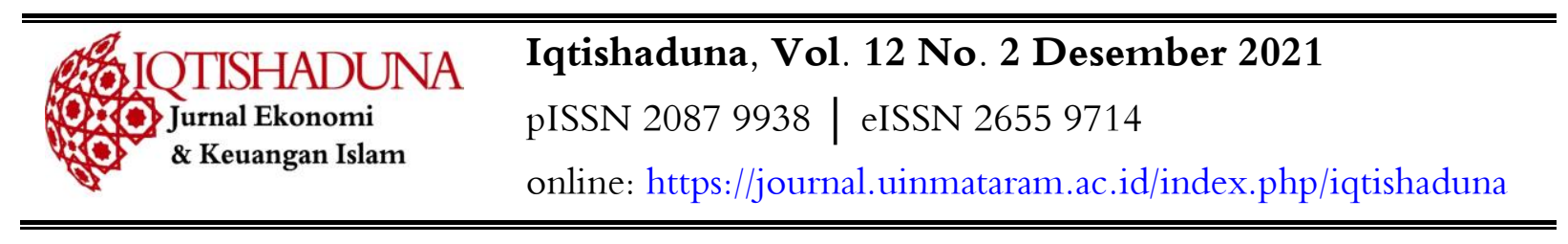

\title{
PENGARUH DIMENSI BANKING SERVICE QUALITY (BSQ) TERHADAP MINAT NASABAH BANK SYARIAH
}

\author{
Lalu Ahmad Ramadani ${ }^{1}$, Rusman Azizoma ${ }^{2}$, Zainal Arifin Haji Munir ${ }^{3}$ \\ Universitas Islam Negeri Mataram ${ }^{1,2,3}$ \\ laluahmdramadani@uinmataram.ac.id ${ }^{1}$.azizomarn@uinmataram.ac.id ${ }^{2}$ \\ zainyanmu@,uinmataram.ac.id ${ }^{3}$
}

\begin{abstract}
Abstrak
Penelitian ini bertujuan untuk menganalisis pengaruh dimensi Banking Service Quality (BSQ) terhadap minat nasabah PT. Bank BNI Syariah. Penelitian ini menggunakan data primer dengan metode analisis regresi linier berganda. Hasil analisis menunjukkan bahwa 4 proksitas dari 6 proksitas dimensi BSQ yaitu keefektifan dan jaminan (Effectiveness dan Assurance), akses (Access), portofolio jasa (Services Portofolio), dan keterwujudan (Tangible) memiliki pengaruh terhadap minat nasabah. Hal ini mengindikasikan semakin banyak jumlah ATM, kualitas teller, kecepatan antrian, keakuratan laporan keuangan, laporan rekening, kebersihan fasilitas, kenyamanan fasilitas, kelengkapan fasilitas serta peningkatan dan menitikberatkan pelayanan jasa bank seperti tabungan, giro, deposito, proses penarikan dan peningkatan pelayanan lainnya seperti pembayaran rekening listri, PDAM serta pembiayaan lainya maka akan meningkatkan minat nasabah.
\end{abstract}

Keywords : Shariah Bank, Banking Service Quality

\section{PENDAHULUAN}

Bentuk dan karakteristik perbankan syariah yang menjalankan sistem bagi hasil, dapat menjadi sistem alternatif yang menguntungkan antara masyarakat (nasabah) dan lembaga keuangan (bank syariah). Hal ini karena mengedepankan aspek keadilan dan etika bertransaksi dengan nilai ukhuwah dalam berproduksi dan menghindari transaksi yang bersifat spekulatif dengan kerangka dual-banking system untuk menciptakan jasa perbankan sebagai alternatif yang semakin lengkap kepada masyarakat dan mendorong mobilisasi transaksi halal (Bank Indonesia, Perbankan Syariah). Perkembangan perbankan syariah tahun 2018 memperlihatkan pertumbuhan asset, pembiayaan dan Dana Pihak Ketiga (DPK) yang terus meningkat dan lebih tinggi dibandingkan tahun sebelumnya pada periode yang sama. Kinerja perbankan syariah pada tahun yang sama secara umum menunjukkan tren positif dari sisi likuiditas dan rentabilitas jika dibandingkan tahun sebelumnya.

Tercatat berdasarkan data statistik Otoritas Jasa Keuangan (OJK) menunjukkan peningkatan jumlah pertumbuhan aset perbankan syariah naik sebesar 13,09\%. Disisi lain, DPK perbankan syariah mencatat pertumbuhan tertinggi dari beberapat faktor kinerja perbankan syariah lainnya. Pertumbuhan DPK mengalami kenaikan sebesar 14,58\%. Sedangkan, 
Ramadani, dkk. Pengaruh Dimensi BS terhadap Minat Nasabah Bank Syariah

Pembiayaan yang diberikan (PYD) perbankan syariah di Indonesia juga mengalami peningkatan. PYD perbankan syariah mencatat pertumbuhan sebesar $11.25 \%$ dan cukup memberikan implikasi pada perkembangan positif pembiayaan Bank BNI Syariah. Pada BNI Syariah sendiri mencapai Rp 25,1 Triliun. Jumlah ini naik sebesar 11,4\%. Dari pembiayaan tersebut, segmen komersial menduduki posisi tertinggi dengan 22,0\% dan diikuti Hasanah Card sebesar 14,6\%, SME 12,3\%, konsumer 7,8\% dan mikro 2,9\%. Komposisi pembiayaan per Juni 2018 terdiri dari segmen Konsumer sebesar Rp 12,9 Triliun (51,5\%). Berdasarkan data tersebut, dapat dilihat bahwa pembiayaan konsumer yang disalurkan merupakan segmen BNI Griya iB Hasanah yakni sebesar 84,9\% pada tahun sebelumnya (portal BNI Syariah).

BNI Syariah mengalami peningkatan yang positif yaitu 3,04\%, posisi ini sebenarnya dibawah rata-rata industri lain yaitu 4,06\%. Tentunya hal ini dipengaruhi oleh kualitas layanan BNI Syariah yang terus meningkat. Sedangkan, Kinerja BNI Syariah Cab. Mataram per Desember 2018 tumbuh positif didukung perolehan DPK mencapai Rp. 210,81 miliar dengan pertumbuhan CASA sebesar 13,96\%. Dari sisi PYD sebesar Rp. 394,31 miliar, naik sekitar 10,04\% jika dibandingkan dengan tahun sebelumnya. Meningkatnya kinerja BNI Syariah Cab. Mataram ini tidak terlepas dari kualitas pelayanan yang dilakukan oleh perbankan syariah khususnya BNI Syariah, yang memberikan dampak baik bagi keberlangsungan operasional perbankan syariah dalam menarik DPK. Pelayanan ini merupakan perilaku yang dilakukan bank dalam aktivitas operasionalnya untuk memenuhi kebutuhan dan keinginan nasabah sehingga dapat menarik minat nasabah dalam menggunakan produk perbankan syariah khusunya produk pembiayaan BNI Griya iB Hasanah.

Dalam melakukan pengukuran kualitas layanan perbankan syariah, khususnya di BNI Syariah Cab. Mataram. Terdapat metode yang biasa digunakan dalam mengukur kualitas layanan atau jasa, yang pertama kali dipopulerkan Bahia dan Nantel yaitu metode Banking Service Quality (BSQ). Metode ini terdiri dari 6 (enam) elemen yaitu: harga (Price), keefektifan dan jaminan (Effectiveness dan Assurance), akses (Access), portofolio jasa (Services Portofolio), kehandalan (Reliability) dan keterwujudan (Tangible). Menurut Ranjith (2013), faktor efektivitas dan jaminan merupakan faktor yang paling penting untuk merepresentasikan kualitas layanan di bank. Namun, penelitian yang dilakukan Sumardiningsih, menunjukkan bahwa keenam dimensi atau variabel BSQ berpengaruh positif signifikan secara simultan terhadap kepuasan nasabah dengan nilai $F=212,327(p<0,05)$. Pengaruh tertinggi dari variabel Reliability dan terendah portofolio jasa (Services Portofolio) dan akses (Access) (Sumardiningsih et al, (2012). Hasil penelitian ini sejalan dengan penelitian yang dilakukan oleh Cahyani (2016) dan Naik (2010) bahwa kualitas pelayanan berpengaruh positif terhadap kepuasan nasabah. Sedangkan, penelitian yang dilakukan 
Munusamy (2010) menunjukkan bahwa jaminan, Tangibles, Empati dan Ketanggapan memiliki hubungan positif dan berdampak signifikan terhadap kepuasan nasabah, namun variabel Reliabilitas memiliki hubungan negatif tetapi tidak berpengaruh signifikan terhadap kepuasan nasabah.

Berdasarkan beberapa penelitian yang telah dilakukan sebelumnya, pembahasan dari penelitian-penelitian tersebut lebih dominan terfokus pada Customer Satisfaction, belum adanya penelitian yang berfokus pada BNI Syariah cab. Mataram dan belum adanya penelitian pada Griya iB Hasanah BNI Syariah mengingat semakin mengeliatnya pembangunan perumahan yang ada di Mataram. Sedangkan, penelitian yang berkaitan dengan minat nasabah masih sedikit terbatas dan terlebih lagi dengan hasil dan objek penelitian yang belum konsisten. Penetapan alat ukur kualitas layanan dalam melihat pengaruhnya terhadap minat nasabah Griya iB Hasanah BNI Syariah mengacu pada metode BSQ yang diukur dengan menggunakan lima elemen yaitu Price, Effectiveness dan Assurance, Services Portofolio, Access, Reliability dan Tangible. Metode ini dianggap mampu merepresentasikan seluruh aspek kualitas layanan, khususnya dalam melihat pengaruhnya terhadap minat nasabah pembiayaan Griya iB Hasanah BNI Syariah cabang Mataram.

\section{METODE}

Jenis data yang digunakan pada penelitian ini adalah data primer. Dalam hal ini, data didapatkan dari kuesioner (Angket) yang diberikan kepada nasabah pembiayaan Griya iB Hasanah BNI Syariah Cab. Mataram. Selain itu juga dilakukan juga observasi dan wawancara kepada pihak front office Bank BNI Syariah cabang Mataram dan kepada nasabah pembiayaan itu sendiri dengan periode penelitian sejak September 2018 sampai dengan dipenuhinya data penelitian yang dimulai dengan pra penelitian sampai dengan terlaksananya laporan penelitian ini. Pengambilan sampel dalam penelitian ini dilakukan dengan teknik insindental yaitu penentuan sampel berdasarkan kebetulan. Siapa saja yang secara kebetulan/insindental bertemu dengan peneliti, maka dapat digunakan sebagai sampel, selama cocok sebagai sumber data dan rumus slovin dalam penentuan jumlah sampel penelitian.

Variabel independen yang digunakan pada penelitian ini adalah Tangible, Price, Access, Service Portofolio, Reliability), serta Effectiveness dan Assurance. Sedangkan variabel dependennya adalah minat nasabah. Analisis data pada penelitian ini menggunakan model regresi berganda dengan model dasar pada penelitian ini adalah sebagai berikut: 
$\mathrm{Y}=\alpha+\beta 1 \mathrm{EFA}+\beta 2 \mathrm{ACC}+\beta 3 \mathrm{PRC}+\beta 4 \mathrm{TAN}+\beta 5 \mathrm{SEP}+\beta 6 \mathrm{REL}+\mathrm{e}$

Dimana:

$\mathrm{Y}=$ minat nasabah

$\alpha \quad=$ Konstanta

$\beta=$ Koefisien regresi pada masing-masing variabel

$\mathrm{EFA}=$ Effectiveness dan Assurance

$\mathrm{ACC}=$ Access

PRC $=$ Price

TAN $=$ Tangible

SEP $=$ Services Portofolio

REL $=$ Reliability

$\mathrm{e} \quad=$ Error

Tujuan penelitian secara universal bersifat penemuan, pembuktian dan pengembangan. Metode penelitian merupakan cara ilmiah yang dihunakan untuk mendapatkan data dengan kegunaan dan tujuan tertentu (Sugiyono, 2006). Dengan demikian, suatu kegiatan ilmiah agar lebih terarah dan rasional memerlukan suatu metode yang sesuai dengan subyek yang akan diteliti, sebab metode berfungsi sebagai cara mengerjakan sesuatau untuk mendapatkan hasil yang optimal dan bisa dipertanggungjawabkan secara ilmiah.

\section{HASIL DAN PEMBAHASAN}

Dalam penelitian yang menggunakan kuesioner sebagai alat pengambilan data, maka sebelum dilakukan analisis statistika inferensial, akan dilakukan uji instrumentasi, yaitu uji validitas dan uji reliabilitas untuk mengukur apakah data yang diperoleh dapat mewakili atau mencerminkan keadaan sesuatu pada diri subjek penelitian.

Validitas merupakan suatu ukuran yang menunjukkan tingkat kesahihan suatu kuesioner karena sesuai dengan dasar pengambilan keputasan valid atau tidaknya, yaitu jika r_hitung $>$ dari r_tabel. Dimana r_tabel nya adalah 0.374. Dimana r_tabel nya adalah 0.374. r_tabel didapatkan dari ketentuan (N-2), maka (43-2=41). Maka N=41, maka r_tabelnya adalah 0.374. Uji reliabilitas digunakan untuk mengukur suatu kuesioner yang merupakan indikator dari suatu konstruk. Suatu kuesioner dikatakan reliabel (handal) jika jawaban seseorang terhadap pernyataan adalah konsisten atau stabil dari waktu ke waktu. Dalam penelitian ini teknik yang digunakan untuk mengukur konsistensi internal adalah koefisien alfa atau cronbanch's alpha. Suatu alat ukur dianggap reliabel apabila nilai cronbach alpha $>0,60$ maka butir atau item pertanyaan tersebut reliabel. Hasil dari Uji Reliabilitas dapat dilihat cronbach alpha 0,964>0,6. 
Sebelum melakukan pengujian terhadap hipotesis, maka terlebih dahulu dilakukan Uji Asumsi Klasik. Uji asumsi klasik ini sangat diperlukan karena merupakan persyaratan dalam analisis regresi berganda. Pengujian ini dimaksudkan agar variabel kualitas pelayanan dan keunggulan produk menjadi estimator bagi variabel minat. Sehingga, nantinya menghasilkan kepastian bahwa persamaan regresi yang diperoleh dapat menghasilkan model dan hasil analisis yang baik, tidak bias dan konsisten, karena terhindar dari gejala-gejala asumsi klasik.

Uji normalitas bertujuan untuk mengetahui apakah data yang digunakan dalam persamaan regresi terdistribusi normal atau dalam regresi variabel dependen dan variabel independen keduanya berdistribusi normal atau tidak normal. Hasil uji normalitas dengan menggunakan uji statistik One Sampel Kolmogorov-Smirnov (K-S), menunjukkan bahwa nilai asymp. Signifikansi $(0,642)$ lebih besar dari 5\% (0,05). Maka, dapat dikatakan bahwa H0 diterima dan H1 ditolak. Hal ini sesuai dengan dasar pengambilan keputusan pengujian yaitu: Jika nilai Sig. > dari 0,05 maka H0 diterima, dan Jika Nilai Sig. < dari 0,05 maka H0 ditolak, dan data tersebut berdasarkan hasil pengujian berdistribusi normal, sehingga dapat digunakan dalam penelitian.

Uji ini bertujuan untuk menguji apakah dalam model regresi terjadi ketidaksamaan varian dari residual satu pengamatan ke pengamatan lain, dapat disimpulkan bahwa pada semua variabel independen tidak terjadi heteroskedastisitas, karena pada nilai sig. Pada semua variabel lebih besar dari 0,05. Hal tersebut sesuai dengan dasar uji Park yaitu: jika nilai Sig. $>$ dari 0,05, maka tidak terjadi masalah heteroskedastisitas, dan sebaliknya jika Sig. $<0,05$, maka terjadi masalah heteroskedastisitas.

Uji multikolinieritas bertujuan untuk menguji apakah model regresi ditemukan adanya korelasi antara variabel independen. Hasil uji Multikolinieritas (Uji VIF), dapat dilihat bahwa nilai tolerance variabel X1 sampai X7 > 0,1 (10\%) dan nilai VIF $<10$, maka dapat disimpulkan bahwa variabel X1 sampai X7 tidak mengalami multikolinieritas artinya tidak adanya hubungan atau korelasi antar variabel independentnya (lolos uji multikolinieritas).

\section{Analisis Regresi Berganda}

Model analisis ini digunakan untuk menilai ketepatan fungsi regresi sampel dalam menaksir nilai aktual dalam artian bahwa apakah data dari sampel yang ada sudah cukup kuat untuk menggambarkan populasinya atau apakah bisa dilakukan generalisasi tentang populasi berdasarkan sampel dan untuk mengetahui pengaruh variabel kualitas pelayanan dan keunggulan produk terhadap minat nasabah pembiayaan iB Griya Hasanah BNI Syariah KCP. Mataram. Hasil Uji Regresi dapat dilihat sebagai berikut:

Persamaan regresi berganda, pengaruh X1 sampai X6 terhadap Y dilakukan analisis koefisien regresi. Hasilnya adalah sebagai berikut: konstanta regresi sebesar 7,425 koefisien 
regresi variabel X1: 0,062. X2: 0,96. X3: 0,128. X4: 0,168. X5: 0,582. X6: 0,387 dan koefisien regresi variabel insentif (X2) sebesar 0,327. Menggunakan tingkat signifikansi sebesar 5\% diperoleh persamaan sebagai berikut:

$$
\mathrm{Y}=7,425+0,062 \mathrm{X} 1+0,96 \mathrm{X} 2-0,128 \mathrm{X} 3+0,168 \mathrm{X} 4+0,582 \mathrm{X} 5+0,387 \mathrm{X} 6-.
$$

Secara statistik, berdasarkan model regresi di atas, setidaknya ketepatan fungsi regresi tersebut dapat diukur dari nilai koefisien determinasi, nilai staistik F dan nilai statistit t. Untuk mengetahui besarnya kontribusi variabel bebas terhadap variabel terkait maka perlu koefisiensi determinannya (R Square). Besaran R Square berkisar antara 0 hingga 1. Apabila R Square mendekati 1 maka semakin besar kemampuan menjelaskan variabel bebas terhadap variabel terkait. Untuk menentukan hasil Uji Koefisien Determinasi, peneliti menggunakan SPSS dan dapat dilihat pada Tabel berikut ini:

\section{Hasil Uji Koefisien Determinasi}

\begin{tabular}{|l|r|r|r|r|}
\hline \multicolumn{1}{|c|}{} & \multicolumn{3}{|c|}{ Model Summary $^{\mathbf{b}}$} \\
\hline Model & R & R Square & $\begin{array}{c}\text { Adjusted R } \\
\text { Square }\end{array}$ & Std. Error of the Estimate \\
\hline 1 &, $708^{\mathbf{a}}$ &, 501 &, 742 & \\
\hline
\end{tabular}

Sumber: Hasil SPSS. Diolah

Berdasarkan perhitungan tabel di atas, nilai adjusted R2 sebesar 0,742 diketahui bahwa hubungan antara X1 sampai X6 dan Y dengan nilai pearson correlation sebesar 0,708. Nilai R dan $\mathrm{R}^{2}$ yang relatif besar ini menunjukkan bahwa $\mathrm{X} 1$ sampai $\mathrm{X} 6$ mempunyai hubungan yang sangat kuat atau dapat dikatakan bahwa X1 sampai X6 pengaruhnya sangat besar terhadap Y, yaitu: kualitas pelayanan dan keunggulan produk secara bersama-sama menjelaskan variasi dependen sebesar $70.5 \%$, dan sisanya $(100 \%-70.5 \%=29.5 \%)$ dijelaskan oleh variabel lain diluar model. Dalam melakukan pengukuran kualitas layanan perbankan syariah, khususnya di BNI Syariah cab. Mataram. Terdapat beberapa teori yang biasa digunakan dalam mengukur kualitas layanan atau jasa, yang pertama kali dipopulerkan oleh Zeithaml dengan metode SERVQUAL yaitu responsiveness, emphaty, tangibles, assurance dan reliability. Namun, konsep ini dianggap belum merepresentasikan seluruh aspek kualitas layanan, khususnya pada bidang perbankan. Maka, Bahia dan Nantel mengembangkan metode baru dalam pengukuran kualitas layanan industri perbankan yang disebut dengan metode Banking Service Quality (BSQ). Metode ini terdiri dari 6 (enam) elemen yaitu: harga (Price), keefektifan dan jaminan (Effectiveness dan 
Assurance), akses (Access), portofolio jasa (Services Portofolio), kehandalan (Reliability) dan keterwujudan (Tangible).

\section{Pengaruh Effectiveness dan Assurance terhadap Minat Nasabah}

Effectiveness and Assurance dengan nilai signifikansinya $0,002<0,05$ artinya berpengaruh positif signifikan terhadap Y. Sehingga dapat disimpulkan bahwa semakin tinggi tingkat kefektifan dan jaminan maka akan makin tinggi minat nasabah. Nilai koefisien regresi sebesar 0,062 artinya apabila dimensi Effectiveness and Assurance meningkat sebesar 1, maka akan meningkat minat nasabah sebesar 0,062. Temuan ini secara umum sejalan dengan temuan penelitian Lassar et al (2000).

\section{Pengaruh Access terhadap Minat Nasabah}

Akses dengan nilai signifikansinya $0,009<0,05$ artinya berpengaruh positif signifikan terhadap Y. Sehingga dapat disimpulkan bahwa semakin tinggi tingkat Access maka akan makin tinggi minat nasabah. Nilai koefisien regresi sebesar 0,096 artinya apabila dimensi Access meningkat sebesar 1, maka akan meningkat minat nasabah sebesar 0,096. Hasil penelitian ini disebabkan oleh jumlah ATM, teller dan kecepatan antrian yang semakin meningkat, maka semakin meningkat minat nasabah.

\section{Pengaruh Price terhadap Minat Nasabah}

Price dengan nilai signifikansinya $0,708>0,05$ dengan nilai koefisien regresi sebesar -0,128 artinya tidak berpengaruh terhadap Y. Temuan ini berimplikasi bahwa makin sepadan harga/biaya yang dikenakan kepada nasabah maka hal tersebut tidak akan memeberikan rangsangan terhadap minta nasabah. Dimensi harga ini tidak pernah masuk dalam model SERVQUAL dan hanya terdapat pada model pengembangan dari SERVQUAL yaitu BSQ. Temuan ini tidak sejalan dengan temuan Indriyatno (2003), bahwa semakin sepada harga atau biaya yang dikenakan kepada nasabah maka akan semakin meningkatkan rangsangan atau pengaruhnya terhadap minat nasabah.

\section{Pengaruh Tangible terhadap Minat Nasabah}

Tangible dengan nilai signifikansinya $0,007<0,05$ artinya berpengaruh positif signifikan terhadap Y. Sehingga dapat disimpulkan bahwa semakin tinggi tingkat Tangible maka akan makin tinggi minat nasabah. Nilai koefisien regresi sebesar 0,168 artinya apabila dimensi Tangible meningkat sebesar 1, maka akan meningkat minat nasabah sebesar 0,168.

Pengaruh positif pada dimensi BSQ ini menunjukkan bahwa semakin tinggi Tangible yang dinilai dari keakuratan laporan keuangan, laporan rekening, kebersihan fasilitas, kenyamanan fasilitas dan kelengkapan fasilitas maka akan semakin meningkat minat nasabah sebesar 0,168 setiap 
kenaikan 1 kelipatan. Hasil penelitian ini sejalan dengan penelitian yang dilakukan oleh Lassar et al (2000).

\section{Pengaruh Reliability terhadap Minat Nasabah}

Reliability dengan nilai signifikansinya $0,708>0,05$ dan nilai koefisien regresi sebesar 0,582 artinya tidak berpengaruh terhadap Y. Menunjukkan bahwa kehandalan dalam pelayanan, tidak memiliki pengaruh terhadap minat nasabah. Temuan ini tidak sejalan dengan beberapa penelitian sebelumnya yang dilakukan oleh Bloomer et al, Angur et al dan Lassar et al (2000).

\section{Pengaruh Services Portofolio terhadap Minat Nasabah}

Service Portofolio dengan nilai signifikansinya $0,004<0,05$ artinya berpengaruh positif signifikan terhadap Y. Sehingga dapat disimpulkan bahwa semakin tinggi tingkat Service Portofolio maka akan makin tinggi minat nasabah. Nilai koefisien regresi sebesar 0,387 artinya apabila dimensi Service Portofolio meningkat sebesar 1, maka akan meningkat minat nasabah sebesar 0,387. Hasil penelitian ini menunjukkan semakin lengkap jasa yang diberikan oleh perbankan maka akan semakin meningkat minat nasabah, artinya bank dituntut untuk mengupayakan peningkatan dan menitikberatkan pelayanan jasa bank seperti tabungan, giro, deposito, proses penarikan dan perlu dalam peningkatan pelayanan lainnya seperti pembayaran rekening listri, PDAM serta pembiayaan lainya.

\section{SIMPULAN}

Berdasarkan hasil penelitian ini tentang pengaruh kualitas pelayanan dan keunggulan produk terhadap minat nasabah pembiayaan Griya iB Hasanah Bank BNI Syariah Cab. Mataram. Maka, dapat diambil kesimpulan dari hasil uji statistik bahwa variable kualitas pelayanan yang diproksikan Effectiveness and Assurance memiliki signifikasi terendah dengan nilai 0,002 <0,05. Hal ini mengindikasikan semakin kecil signifikasinya maka semakin besar pengaruh yang ditimbulkan terhadap minat nasabah pembiayaan Griya IB Hasanah BNI Syariah cab. Mataram. Hal ini terjadi karena kepercayaan nasabah kepada bank syariah, baik berkaitan kerahasiaan nasabah dalam jumlah pembiayaan dan rekening, Pegawai atau karyawan BNI Syariah cab. Mataram terlatih dengan baik dalam memberikan pelayanan kepada nasabah sebagaimana yang telah dijanjikan BNI Syariah cab. Mataram.

\section{REFERENSI}

Angur, Madhukar G., Rajan Nataraajan dan Joh S. Jahera, Service Quality In The Banking Industry: An Assessment In A Developing Economy, International Journal of Bank Marketing, 1999, Vol. 16 No.7, p.116-123. 
Bank

Indonesia,

Perbankan

Syariah,

https://www.bi.go.id/id/perbankan/syariah/Contents/Default.aspx. Diakses tanggal 6 Oktober 2018.

Bloomer, Josee, Ko De Ruyter Dan Pascal Peeters, Investigating Drivers Of Bank Loyalty: The Complex Relationship Between Image, Service Quality An Satisfaction, International Journal Of Bank Marketing,1998, Vol. 6 No. 7, p. 276-286.

BNI Syariah, produk Griya iB Hasanah, www.bnisyariah.co.id/id-id/personal/bnigriyaibhasanah. Diakses tanggal 6 Oktober 2018.

BNI Syariah, perkembangan BNI Syariah, https://www.bnisyariah.co.id/enus/home/news/pressrelease/ArticleID/1374/kinerja-bni-syariah-tumbuh-positif-ditriwulan-2-tahun-2018. Diakses tanggal 6 Oktober 2018.

Cahyani, Putri Dwi. "Tingkat Kepuasan Nasabah Terhadap Kualitas Layanan Perbankan Syariah di Yogyakarta." Esensi: Jurnal Bisnis dan Manajemen, Vol. 6. No. 2, (2016), 151-162.

Indriyatno, Murdiyanto. Pengaruh Dimensi-Dimensi Kualitas Pelayanan Jasa Perbankan (Banking Service Quality) Terhadap Kepuasan Nasabah Tabungan Britama (Studi Kasus Pada Kantor Cabang Bank Rakyat Indonesia Manado). Tesis. Program Pasca Sarjana Universitas Diponegoro, 2003.

Lassar, W.M., Manolis, C. and Winsor, R.D, Service Quality Perspectives And Satisfaction In Private Banking. The Journal Of Services Market, Vol. 14 No. 3, pp. 244-271.

Munusamy, Jayaraman, Shankar Chelliah, and Hor Wai Mun. "Service quality delivery and its impact on customer satisfaction in the banking sector in Malaysia." International Journal of Innovation, Management and Technology, Vol. 1, No. .4, (2010), 398.

Naik, CN Krishna, Swapna Bhargavi Gantasala, and Gantasala V. Prabhakar. "Service quality (SERVQUAL) and its effect on customer satisfaction in retailing." European journal of social sciences, Vol. 16, No. 2, (2010), 231-243.

Otoritas Jasa Keuangan, Snapshot Perbankan Syariah Indonesia, www.ojk.go.id/id/kanal/syariah/berita-dan-kegiatan/publikasi/Pages/Snapshot-

Perbankan-Syariah-Indonesia-Juni-2018.aspx. Diakses tanggal 6 Oktober 2018.

Ranjith, P. V. "Service quality in banking." International Journal of Management Research and Reviews, Vol. 3, No. 9, (2013), 3463.

Sugiono, Metode Penelitian Kuantitatif, Kualitatif dan R\&D, (Bandung: Alfabeta, 2006), 2.

Sumardiningsih, Sri, et al. "Pengaruh Dimensi Banking Service Quality (BSQ) terhadap Kepuasan Nasabah Bank." Jurnal Economia, 126-134. 